\title{
Evidence for deep sub-surface flow routing in forested upland Wales: implications for contaminant transport and stream flow generation
}

\author{
Atul H. Haria ${ }^{1}$ and Paul Shand ${ }^{2}$ \\ ${ }^{1}$ Centre for Ecology and Hydrology, Maclean Building, Crowmarsh Gifford, Wallingford, Oxfordshire OX10 8BB, UK \\ ${ }^{2}$ British Geological Survey, Crowmarsh Gifford, Wallingford, Oxfordshire OX10 8BB, UK \\ Email for corresponding author: atu@ceh.ac.uk
}

\begin{abstract}
Upland streamflow generation has traditionally been modelled as a simple rainfall-runoff mechanism. However, recent hydrochemical studies conducted in upland Wales have highlighted the potentially important role of bedrock groundwater in streamflow generation processes. To investigate these processes, a detailed and novel field study was established in the riparian zone and lower hillslopes of the Hafren catchment at Plynlimon, mid-Wales. Results from this study showed groundwater near the river behaving in a complex and most likely confined manner within depth-specific horizons. Rapid responses to rainfall in all boreholes at the study site indicated rapid recharge pathways further upslope. The different flow pathways and travel times influenced the chemical character of groundwaters with depth. Groundwaters were shown to discharge into the stream from the fractured bedrock. A lateral rapid flow horizon was also identified as a fast flow pathway immediately below the soils. This highlighted a mechanism whereby rising groundwater may pick up chemical constituents from the lower soils and transfer them quickly to the stream channel. Restrictions in this horizon resulted in groundwater upwelling into the soils at some locations indicating soil water to be sourced from both rising groundwater and rainfall. The role of bedrock groundwater in upland streamflow generation is far more complicated than previously considered, particularly with respect to residence times and flow pathways. Hence, water quality models in upland catchments that do not take account of the bedrock geology and the groundwater interactions therein will be seriously flawed.
\end{abstract}

Keywords: bedrock, groundwater, Hafren, hillslope hydrology, Plynlimon, recharge, soil water, streamflow generation

\section{Introduction}

The British uplands, dominated by hard-rock geology, are the source of some of the major river systems in the UK; they constitute a major water resource. The mechanism of stream flow generation in these upland regions was thought to be a simple rainfall-runoff process where the bedrock geology was considered impermeable. Early hydrological research in the uplands was based on the implicit assumption that these catchments were sealed beneath the soils and that soil water was the main source of streamflow, particularly during storm events (Kirby et al., 1991). One of the reasons for this assumption was the rapid streamflow response (23 hours) following the start of a rainfall event. The Pumlumon (Plynlimon) catchments in mid-Wales were established by the Institute of Hydrology (now Centre for Ecology and Hydrology) in the late 1960s as a long-term hydrological study to assess the differences in the water balance between the forested Hafren (Severn) and moorland Gwy (Wye) catchments (Kirby et al., 1991). Hydrological rainfall-runoff monitoring was augmented by water quality monitoring in the mid-1980s that rose to the fore in the 1990s. Much of the early work on hydrochemistry was completed in response to concerns about the susceptibility of surface waters to acid rain and consequent stream acidification.

Long term hydrochemical data collected in the Hafren provided the first indication that upland streamflow generation was not a simplistic rainfall-runoff process and that a far more complex system was at work. Neal et al. (1988) described the discrepancy between concentrations of the inert natural tracer chloride in rainfall and the much more damped chloride signal of storm flow response. A similar catchment damping was also observed for oxygen isotopes (Neal and Rosier, 1990) and conductivity (Robson 
et al., 1993). Whilst the hydrological response of the catchment could be reproduced reasonably well, the rainfallrunoff models failed to reproduce the damped response in the chloride signal (Neal et al., 1988). Although the work indicated the presence of a hydrological 'mixing-pot' the location and mechanisms of mixing, whereby the rainfall chloride signal is damped, still remain unresolved. This has highlighted the poor understanding of upland streamflow generation processes under both baseflow and stormflow conditions.

Subsequent attempts to explain the chloride damping and therefore the likely mechanisms of upland streamflow generation have stressed the concept of 'new' and 'old' water components in the catchment soils (Neal et al., 1988; Robson et al., 1993). Soulsby (1995) concluded that storm runoff in upland Wales generally caused the displacement of 'old' pre-event water to dominate the storm hydrograph. Similarly, Sklash et al., (1996) showed that the water flowing through soil pipes during storm events in the Gwy catchment at Plynlimon was overwhelmingly 'old' water. The importance to streamflow processes of transient perched water-table development in the riparian zone soils at Plynlimon was highlighted by Chappell et al. (1990); however the movement of water to the near-stream riparian area remained unexplained. More recently, Chen et al. (2002) used a nonconservative mixing model to explain the chloride damping observed in the Hafren catchment, citing adsorptiondesorption or diffusion processes as a control of stream chloride concentrations. This hypothesis, however, cannot explain the concurrent stable isotope damping also observed at Plynlimon (Sklash et al., 1996; Neal and Rosier, 1990).

The presence of an active bedrock groundwater system in the Hafren catchment was observed in the mid-1990s and was considered important as a source of baseflow (Neal et al., 1997). However, the mechanistic role of this groundwater resource in damping the rainfall chloride signal and its role in stormflow response remains unclear. Recent research using fractal analysis of the Plynlimon chloride data (Kirchner et al., 2000., 2001) has revealed important information on pathways by indicating that a range of travel time distributions are necessary to explain observed chloride trends in stream water within the catchment. The first clear evidence of the importance of a bedrock groundwater component in streamflow response at Plynlimon was by Shand et al. $(1997,2001)$ who used strontium isotopes to show that the river waters lie on a mixing line between groundwater and rainfall.

Despite the presence of deep bedrock groundwater (Neal et al., 1997; Shand et al., 2001), many hillslope hydrologists still use the term groundwater to mean water perched in the soil horizons. The concept of a deeper bedrock groundwater resource (extending down to many 10 s of metres depth) has been poorly understood and is consequently often ignored. Whilst saturation in soils can also technically be termed groundwater, in this paper the term groundwater refers specifically to the permanent saturated horizons in the bedrock. Although bedrock groundwater can rise into the soils causing saturation, its origins are wholly different to rainfall-derived perched saturated horizons in the soils.

It is apparent that there is a lack of knowledge of how rainfall, soil water and groundwaters travel and mix within a catchment during storm flow events, particularly in the riparian zone, and the implications of this mixing for stream water quality (Kirchner, 2003). An understanding of these processes is crucial to the management of forested uplands in developing a sustainable aquatic ecosystem, fisheries and potable water resource.

To address these issues, a detailed physico-chemical process study was established in the forested Plynlimon catchment of the Afon Hafren (River Severn), mid-Wales, UK. An experimental transect from the stream riparian zone and lower hillslope was instrumented intensively to study soil, stream and groundwater pathways and mixing processes. Aquifer characterisation was established using nests of boreholes that were sealed to specific depths using novel techniques to isolate and sample separate bedrock groundwater components. Storm responses along the transect in these depth specific groundwater compartments were characterised at the site. The aim of this study was to assess the role of near-river bedrock groundwater in streamflow generation processes and to determine the role of groundwater as a hydrochemical 'mixing-pot' that might explain the damped response of conservative tracers. This paper presents the preliminary (mainly physical) results from groundwater monitoring in this study and tests the hypothesis that groundwater inputs into the river may be significant.

\section{Methods}

\section{SITE DESCRIPTION}

The study site on the south-west facing slope of the forested Hafren catchment at Plynlimon, mid-Wales is shown in Fig. 1. The Hafren Transect (shown in plan view, Fig. 2) was a plot approximately $50 \mathrm{~m}$ by $10 \mathrm{~m}$ that incorporated the riparian zone and lower hillslope of the Afon Hafren. A soil pit excavated about $20 \mathrm{~m}$ up-river from the study site showed the soil profile to be a stagnopodzol. The profile was a $0.13 \mathrm{~m}$ thick peat A horizon overlying a $0.07 \mathrm{~m}$ thick clay leached Ea horizon. Below this was a $0.28 \mathrm{~m}$ thick ochreous iron-rich $\mathrm{B}$ horizon comprising an orange/red silty- 


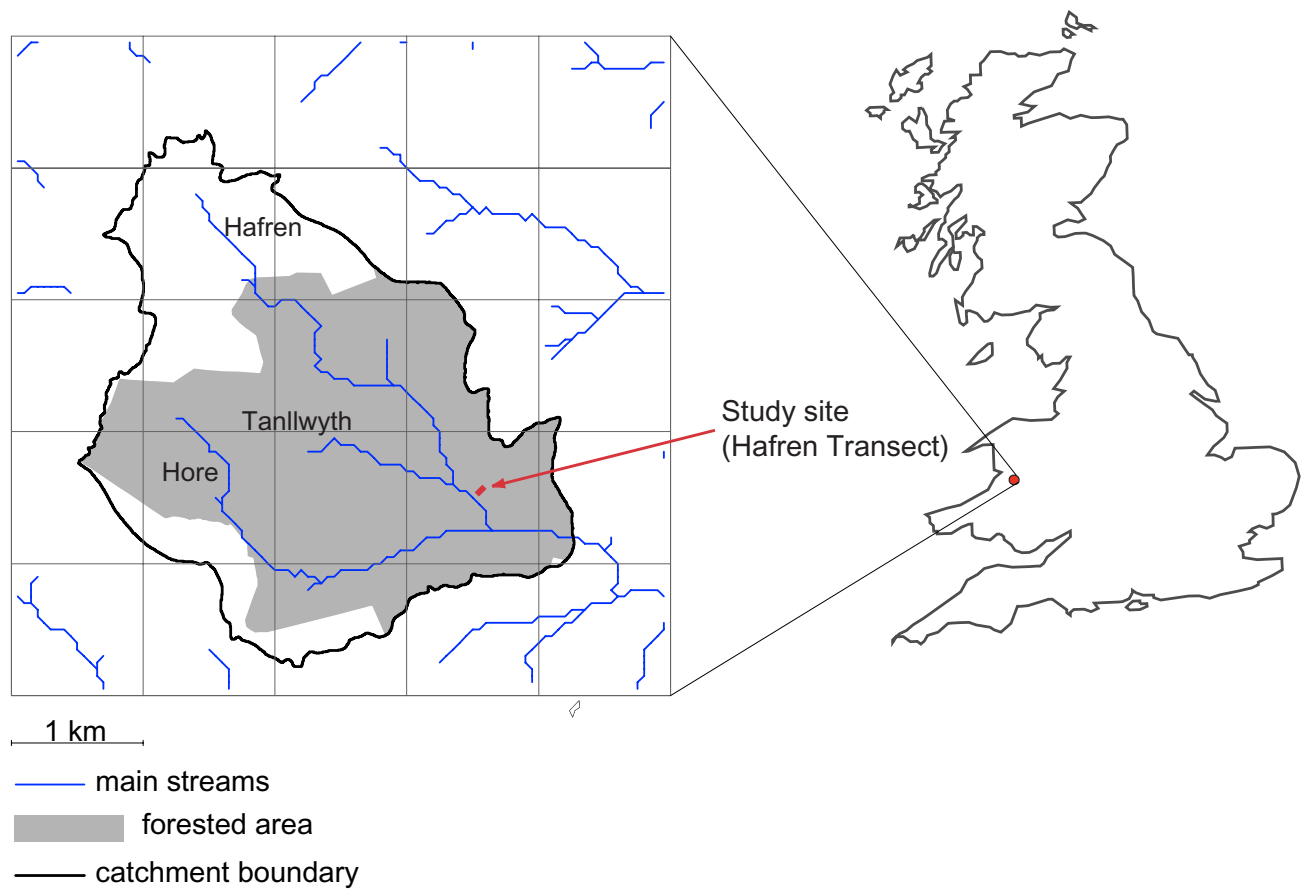

Fig. 1. Location of the study site in the forested Hafren catchment, mid-Wales.

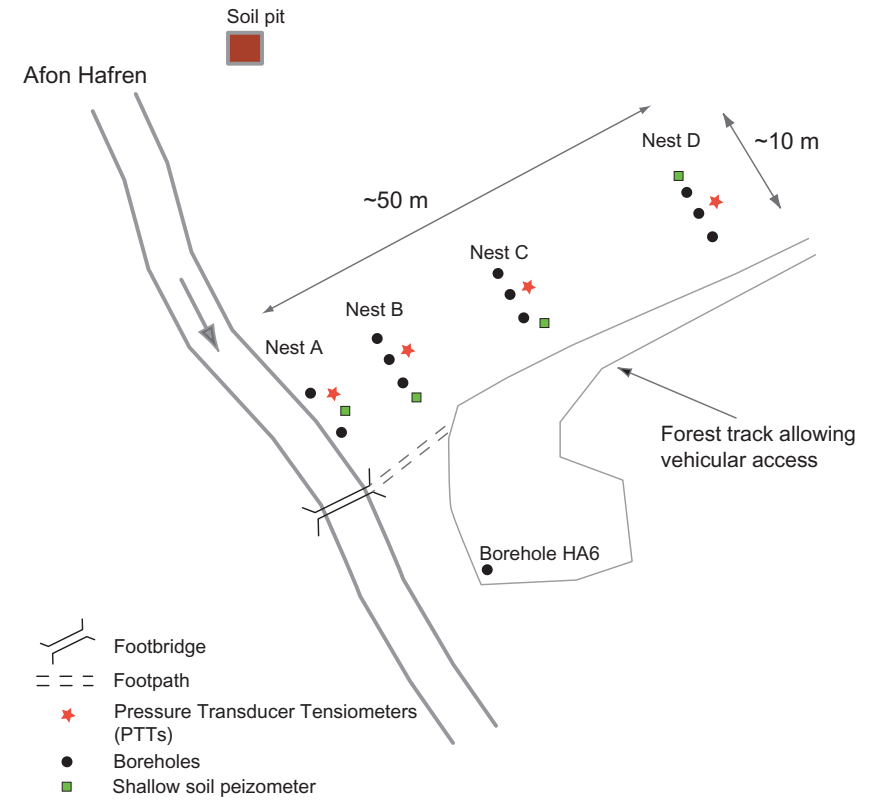

Fig. 2. Schematic plan view of the Hafren Transect study site.

clay matrix with incorporated fragments of mudstone increasing with depth. Below $0.48 \mathrm{~m}$ depth, an olive-green colour change was observed indicating more anaerobic conditions.

The catchment geology is primarily Ordovician and Silurian shales and mudstones. The rock mass characteristics varied considerably with depth and three distinct horizons were identified at this site from drilling and geophysical logs:

(a) an extremely fractured bedrock horizon $(\sim 0.5-1.0 \mathrm{~m}$ thick, although spatially this thickness varies considerably) beneath the soils resulting from intense weathering. This horizon was about $1.0-1.5 \mathrm{~m}$ from the soil surface;

(b) a less weathered shallow bedrock horizon extending from about $1.5 \mathrm{~m}$ depth to about $10-15 \mathrm{~m}$ depth;

(c) deeper consolidated bedrock with discrete flow horizons below about $15 \mathrm{~m}$ depth.

\section{THE HAFREN TRANSECT}

To observe near-stream bedrock groundwater processes, a transect of four Nests of boreholes (A to D) was installed from the river to the lower hillslope (Figs. 2 and 3 ). Boreholes (BHs) were drilled into the extremely fractured bedrock horizon (BHs 1, 1.5 m depth), the less weathered shallow bedrock (BHs 2, 10 m depth) and the deep consolidated bedrock (BHs 3, 30 m depth); exact borehole depths are given in Table 1. The boreholes in Nests B to D were drilled to $90 \mathrm{~mm}$ diameter with a Down-The-Hole (DTH) hammer using a rotary percussion drilling rig with air flush for a $50 \mathrm{~mm}$ (2 inch) completion. The soil was cased off with steel drill casing to prevent collapse and 


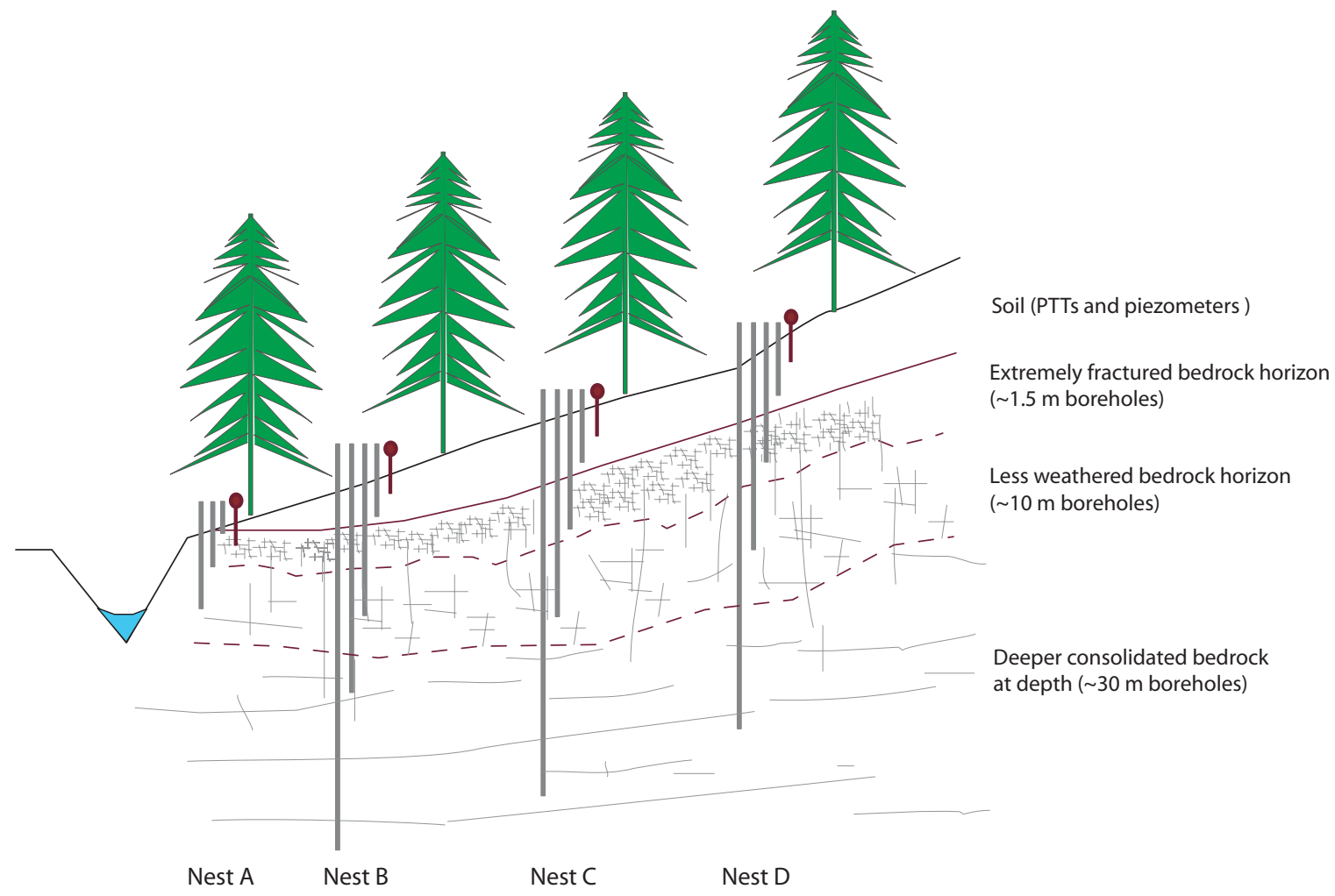

Fig. 3. Schematic cross-section of the Hafren Transect study site.

Table 1. Borehole construction details.

\begin{tabular}{lllll}
\hline Site & $\begin{array}{l}\text { Nest A } \\
\text { Total borehole penetration }\left(\text { mbgl }^{\dagger}\right)\end{array}$ & Nest D \\
& & Nest B & Nest C \\
\hline Borehole 1 (BH 1) & $1.3(0.35)$ & $1.5(0.60)$ & $1.5(0.55)$ & $1.58(0.31)$ \\
Borehole 2 (BH 2) & $8.39(3.24)$ & $9.2(3.26)$ & $10.0(4.35)$ & $7.44(3.00)$ \\
Borehole 3 (BH 3) & - & $30.3(5.13)$ & $27.3(7.45)$ & $25.3(5.18)$ \\
& & & & \\
$\left({ }^{\dagger}\right.$ mbgl = metres below ground level) & & & \\
$($ Screened interval at bottom of each borehole shown in parentheses $(m))$
\end{tabular}

contamination of the aquifer. Geophysical logging of the three deepest $(\sim 30 \mathrm{~m})$ open holes was undertaken prior to well completion. For the deeper boreholes (BHs 2 and 3, Nests B to D), $50 \mathrm{~mm}$ plastic well casing, slotted below a chemically hygroscopic expanding packer, was installed in each borehole. Nest A, closest to the river, consisted of two boreholes drilled using a hand held rotary percussion system with air flush to $57 \mathrm{~mm}$ diameter for completion with $19 \mathrm{~mm}$ diameter plastic well casing. Difficult access meant a drilling rig could not be used and so the deepest borehole $(\sim 30 \mathrm{~m}$ depth) could not be installed at Nest A. The plastic well casings for all boreholes were extended sufficiently above ground level to allow measurement of artesian heads.
Since the aim was to sample discrete depth specific groundwater, the annular gap above the packer had to be sealed to prevent cross-contamination. Standard sealing practice is to use bentonite or cement but, because of problems with bridging and the potential for chemical reaction with groundwater, an alternative inert system had to be found; a two-part expanding polyurethane resin was used successfully to seal the annular gap above the packer to the surface. For the extremely fractured bedrock zone boreholes, to ensure a watertight seal, the soil immediately around the steel casing was excavated and sealed with polyurethane expanding resin resulting in a watertight foam seal. Details on the screened interval at the bottom of each 
Table 2. Site survey information

\begin{tabular}{|c|c|c|c|c|}
\hline Nest & $\begin{array}{l}\text { Borehole } \\
\text { Identifier }\end{array}$ & $\begin{array}{l}\text { Ground level } \\
\text { height above } \\
\text { Datum }^{+}(m)\end{array}$ & $\begin{array}{l}\text { Average height of } \\
\text { each borehole group } \\
\text { above Datum }(m)\end{array}$ & $\begin{array}{l}\text { Distance of each Nest } \\
\text { from River }(m)\end{array}$ \\
\hline $\begin{array}{l}\text { A } \\
\text { (closest } \\
\text { to river) }\end{array}$ & $\begin{array}{l}\mathrm{BH} 1 \\
\mathrm{BH} 2\end{array}$ & $\begin{array}{l}1.0 \\
0.69\end{array}$ & 0.85 & 3 \\
\hline B & $\begin{array}{l}\mathrm{BH} 1 \\
\mathrm{BH} 2 \\
\mathrm{BH} 3\end{array}$ & $\begin{array}{l}2.97 \\
3.44 \\
3.11\end{array}$ & 3.17 & 12.5 \\
\hline $\mathrm{C}$ & $\begin{array}{l}\mathrm{BH} 1 \\
\mathrm{BH} 2 \\
\mathrm{BH} 3\end{array}$ & $\begin{array}{l}4.32 \\
4.18 \\
4.72\end{array}$ & 4.41 & 27.5 \\
\hline D & $\begin{array}{l}\mathrm{BH} 1 \\
\mathrm{BH} 2 \\
\mathrm{BH} 3\end{array}$ & $\begin{array}{l}5.86 \\
5.48 \\
5.98\end{array}$ & 5.77 & 44 \\
\hline
\end{tabular}

†The Datum used was a point marked on the stone foundation of a footbridge over the river at the study site (Fig. 2). The datum was $3.06 \mathrm{~m}$ above the bed of the river measured at the footbridge.

borehole are shown in parentheses in Table 1. In this way the data collected from the boreholes were depth specific. Previous groundwater studies in open boreholes at Plynlimon resulted in mixing of different groundwaters so that those observations were difficult to interpret.

The site was surveyed and the results are shown in Table 2. The ground level height above a datum for each borehole is shown, along with the average height of the group of boreholes in each Nest. The distance of each Nest from the river was measured to within $\pm 0.5 \mathrm{~m}$; measurements close to the river were difficult because of the steep hazardous river bank.

Shallow soil piezometers were installed at each Nest to sample any water saturation (perched water) in the A horizon peat on top of the clay-rich Ea horizon. The peaty A horizon was thicker $(\sim 0.3 \mathrm{~m}$ thick) at the transect site than in the excavated pit up-river. Consequently, $40 \mathrm{~mm}$ diameter simple standpipe piezometers were installed in $90 \mathrm{~mm}$ handaugered (through access tubes) holes to about $0.3 \mathrm{~m}$ depth. Water, if present, was collected through a $0.1 \mathrm{~m}$ screen at the base which was again isolated from the surface by the use of expanding foam.

Water levels in each of the boreholes (but not soil piezometers) were measured hourly using pressure transducers connected to data loggers. Rainfall data, measured hourly at a meteorological site at the confluence of the Hafren and Tanllwyth (about $250 \mathrm{~m}$ upstream from the Hafren Transect), were used in this study. Data were collected from September 2000 to March 2002.

Groundwater samples were taken from the boreholes on 19 July 2000 using pumps permanently installed in each well. The variables $\mathrm{pH}$, specific electrical conductance (SEC) and redox potential (Eh) were measured in a flow through cell (to avoid contact with the atmosphere) in the field.

\section{Results and discussion}

\section{TIME SERIES ANALYSIS}

Rainfall and groundwater level data collected between 7 September 2000 and 19 March 2002 are shown as time series plots in Figs. 4a and b. Groundwater levels in each of the sealed boreholes are shown as metres relative to ground level (mrgl) at each borehole for Nest D, highest upslope, through to Nest A, closest to the river.

Evidence that this site is more complex than a simple unconfined aquifer is presented in Fig. 4 where the groundwater levels shown for the boreholes in each Nest do not increase or decrease in order with depth. For example, at Nest D the highest heads were recorded for the intermediate borehole BH 2. Geophysical logs of the open boreholes (data not shown) showed groundwater inflows into the boreholes from discrete fractures. This information, 


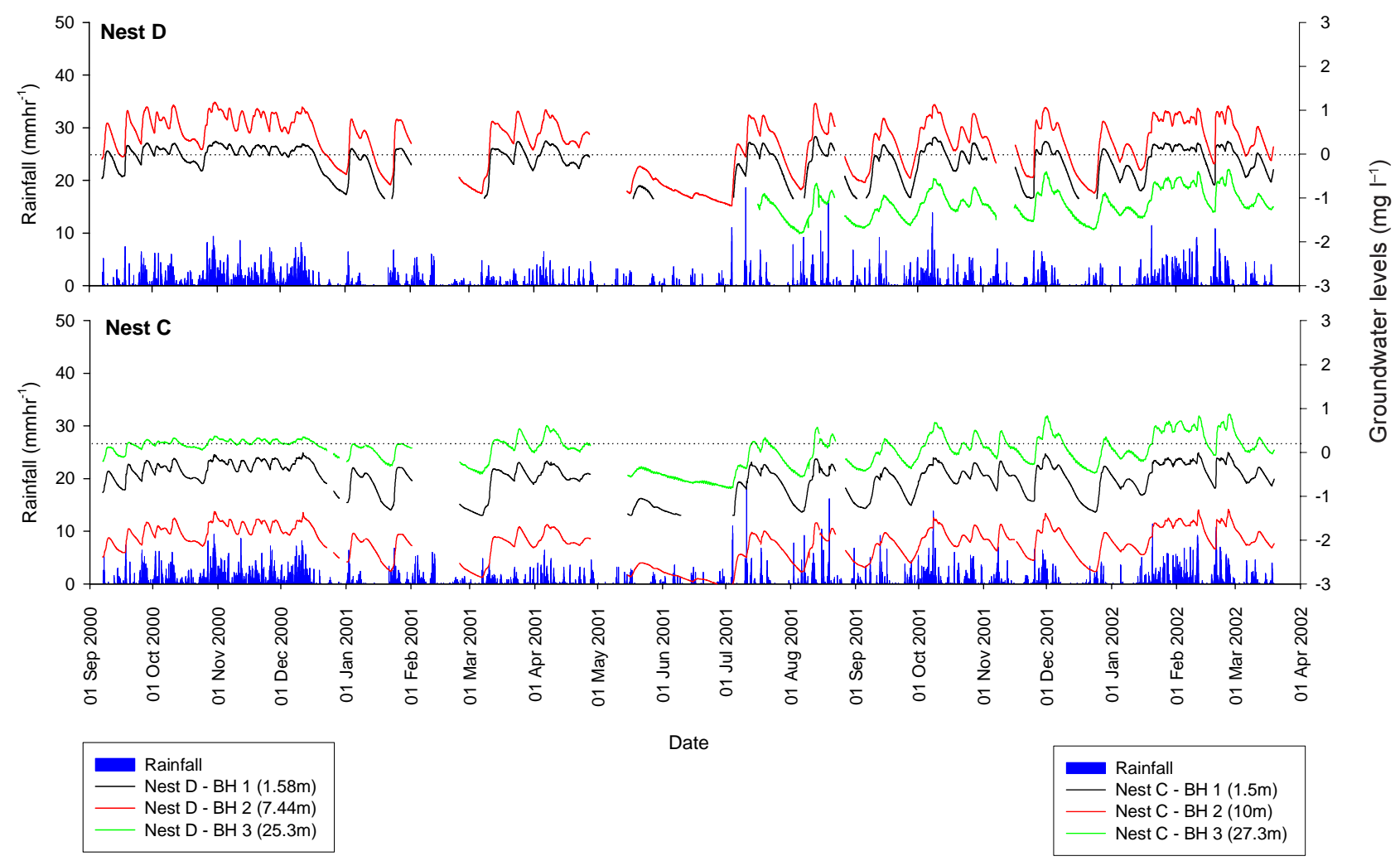

Fig. 4a. Time-series groundwater level data from the sealed boreholes at Nest D and Nest C. (mrgl: metres relative to ground level)

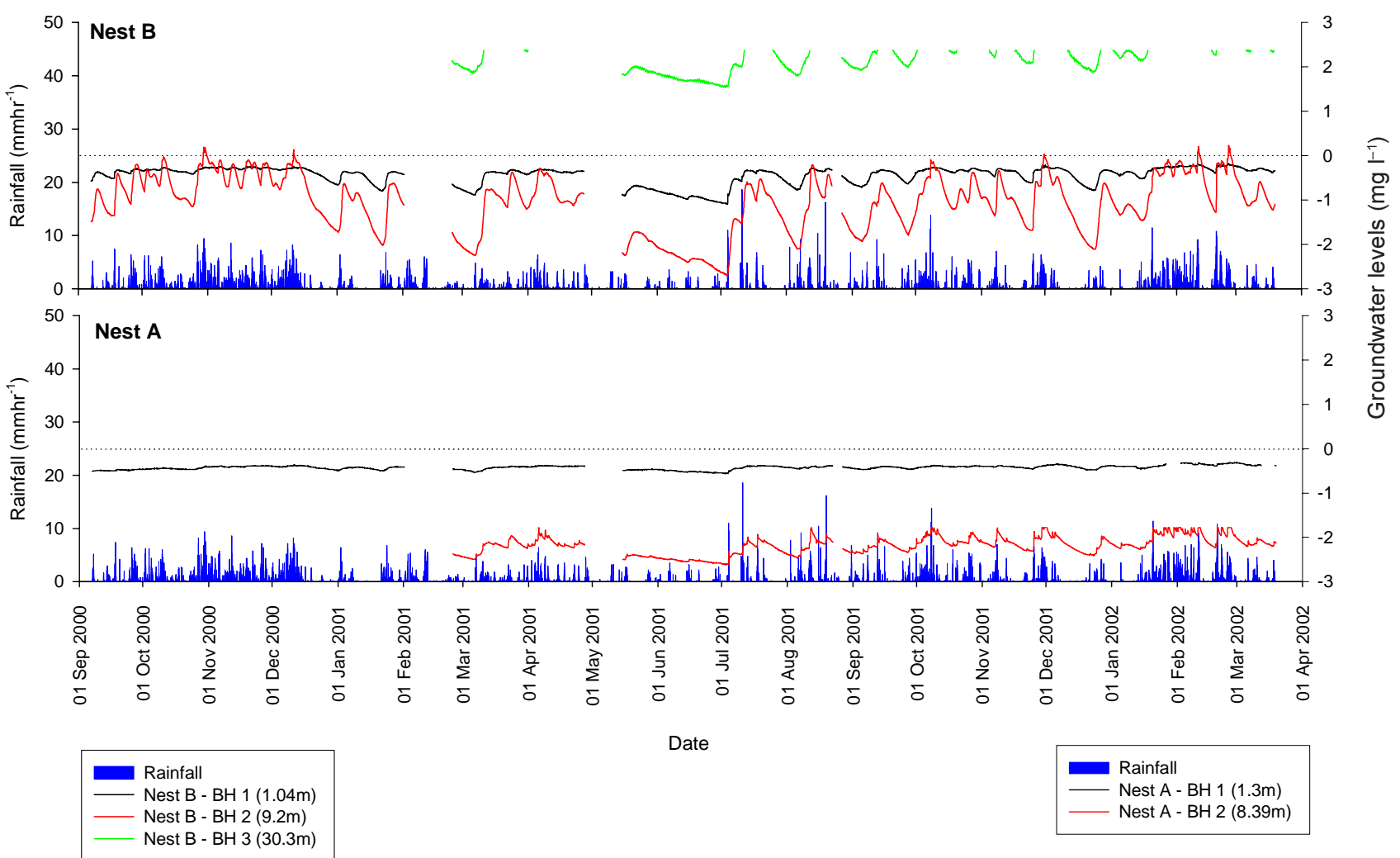

Fig. 4b. Time-series groundwater level data from the sealed boreholes at Nest B and Nest A. (mrgl: metres relative to ground level) Data for BH3, Nest B, could only be recorded to a maximum height of $2.4 \mathrm{~m}$ above ground level because of well height limitations. 
combined with hydrochemical data from the boreholes (presented later), indicates a complex aquifer system and suggests that the deeper groundwaters are likely to be confined at the study site.

Groundwater levels in many of the boreholes were artesian close to the river (Fig. 4). Groundwaters responded rapidly to rainfall at ALL depths for Nests D and C (Fig. 4a). The rise in groundwater generally occurred within 2-3 hours from the start of rainfall; the exact timing was dependent on rainfall intensity, volume and antecedent soil moisture status. The responses result from a hydrostatic response to rapid recharge somewhere upslope from the boreholes. The almost identical groundwater behaviour at all depths (Nests $\mathrm{D}$ and $\mathrm{C}$ ) shows the same rapid recharge mechanism feeds the upslope groundwater system, including the deeper groundwaters which are likely to be confined in depthspecific horizons at the Hafren Transect study site close to the valley bottom. Recharge to these deeper groundwaters does not occur at the study site close to the river. The location and mechanism of these upslope rapid recharge processes has yet to be established. However, forestry practices such as digging drainage ditches in the forests and along forestry roads might possibly enhance groundwater recharge processes that bypass the soil horizons.

Figure $4 \mathrm{~b}$ shows similarly rapid responses of groundwater levels to rainfall for Nests B and A. The rapid responses are more evident for the deeper BH $2(\sim 10 \mathrm{~m})$ boreholes; data for BH $3(\sim 30 \mathrm{~m})$, Nest B, is truncated because the height of the well casing was limited to $2.4 \mathrm{~m}$ above ground level and water levels beyond this could not be recorded. Rapid groundwater responses in BHs $1(\sim 1.5 \mathrm{~m})$ at Nests B and A were less discernable because of an attenuation in amplitude of the groundwater responses with increasing proximity to the stream (Fig. 4b). The decrease in amplitude of response is controlled by the outflow boundary where the groundwater is discharging along the stream bank. The groundwater head gradient increases with increasing rainfall; consequently smaller changes in groundwater level are observed with increasing proximity to the river. This response indicates discharge from this groundwater horizon into the stream.

A maximum plateau in groundwater levels (evident from mid-Jan 2002 to end-Feb 2002) in BH 2 ( $10 \mathrm{~m}$ horizon), Nest $A$, is shown in Fig. 4b. Unlike the maximum rise recorded in BH 3 (Nest B), this was not a result of the limitations of well height; the most likely explanation is discharge into the river from the stream bank along fracture pathways truncated by the river channel. Groundwater seepage from the riverbank was also observed both through what appeared to be the soils and also through discrete fractures in the bedrock. This is supported by the fact that the soil above the points of seepage in the riverbank was generally dry; the shallow soil piezometers in Nests B and $\mathrm{C}$ were empty of water indicating a groundwater source for the bank seepage.

Groundwater level changes for BH 2, Nest A were also more rapid and responded to rainfall patterns more closely than for the other $\sim 10 \mathrm{~m}$ boreholes in the transect where the responses showed a much smoother response. This is because of the lower storage capacity in the smaller diameter borehole at Nest A $(19 \mathrm{~mm})$ compared to the boreholes (50 $\mathrm{mm})$ at the other Nests.

\section{FIELD HYDROCHEMICAL CHARACTERISTICS}

The groundwaters showed extreme variations with depth in $\mathrm{pH}$, Specific Electrical Conductance (SEC) and redox characteristics. Groundwaters in the extremely fractured bedrock horizon $(\sim 1.5 \mathrm{~m})$ and the less weathered shallow bedrock horizon ( $\sim 10 \mathrm{~m})$ were oxidising and acidic $(\mathrm{pH} 4.9$ to 5.3) with low SEC (Fig. 5) indicating a relatively short residence time. The $\sim 10 \mathrm{~m}$ boreholes had values of $\mathrm{pH}$ similar to the shallowest groundwaters but slightly higher SEC. In contrast, the deeper $(\sim 30 \mathrm{~m})$ boreholes produced groundwater with much higher SEC and high $\mathrm{pH}(\mathrm{pH} 7.7$ to 8.8). These were also reducing (Eh, referenced to SHE (Standard Hydrogen Electrode), varied from -24 to $-79 \mathrm{mV}$ ) and a distinct smell of $\mathrm{H}_{2} \mathrm{~S}$ was observed during pumping. The deeper groundwaters, therefore, appear to have had a much longer residence time.

Stream water collected adjacent to the study site was similar to the shallow groundwaters but had slightly lower SEC (Fig. 5) indicating the presence of a more dilute source further upstream. Discharge to the stream was seen to occur along the river bank and samples collected were identical with the shallow groundwater sampled from the boreholes. This supports the physical evidence of shallow groundwater discharging directly from the bank into the river. Taking into account the high SEC in the deeper groundwaters, it is unlikely that these form a significant direct input to the rivers at this site.

The difference in chemistry at different depths confirms the evidence from physical data for a discrete compartmentalised system of fractures at the study site. Furthermore, knowledge of the presence of such alkaline groundwaters at depth was made possible only by sampling depth specific horizons in the bedrock, thus avoiding mixing in open boreholes.

\section{GROUNDWATER PROCESSES}

Figure 6 shows the relationship between the groundwater levels recorded in the extremely fractured bedrock strata 

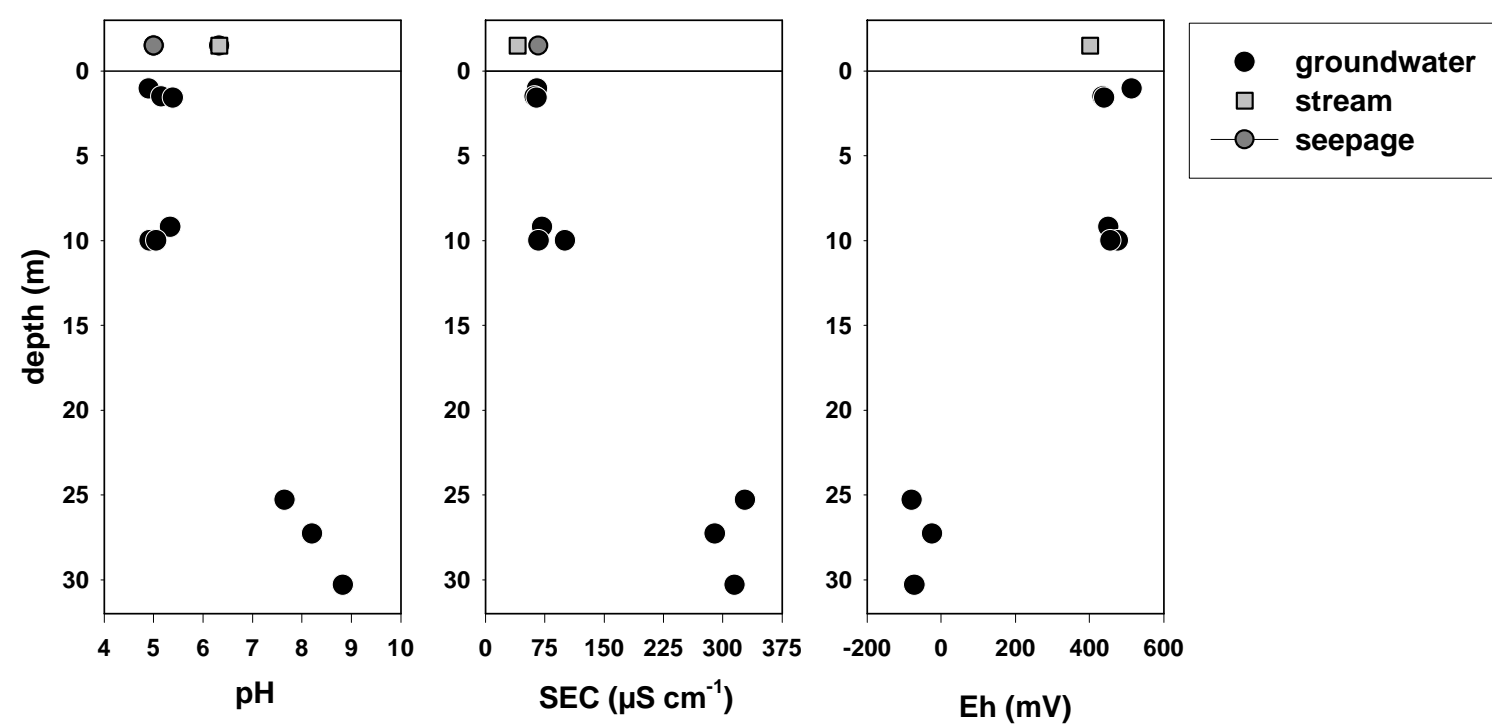

Fig. 5. Variations in hydrochemical parameters with depth from the nested boreholes. The graph shows data from each of the boreholes in Nests $B$ to $D$.

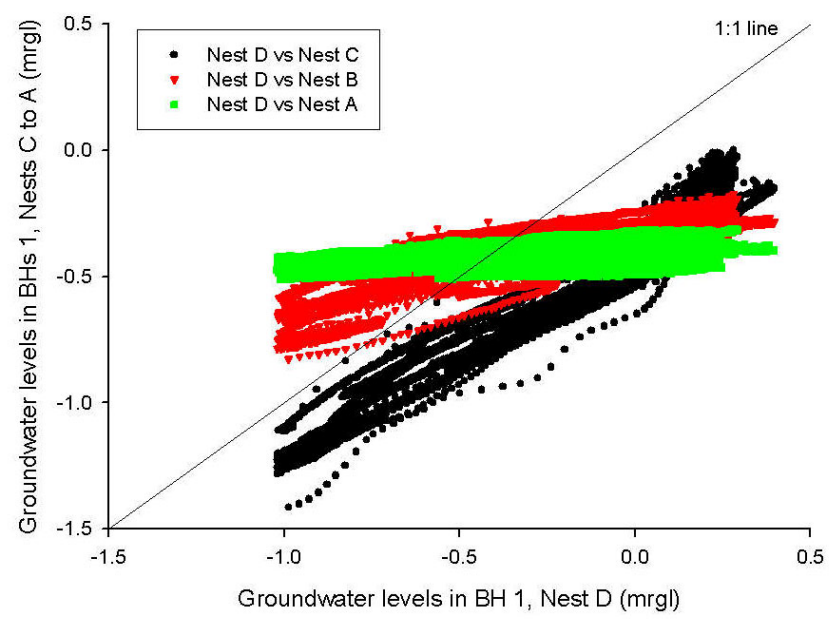

Fig. 6. Correlation between BH I $(\sim 1.5 \mathrm{~m})$ groundwater levels at Nest D and Nests C to A.

(BH 1, 1.5 m depth) at all the Nests. The relationship between Nest D and Nest C generally follows the 1:1 line (although offset) and shows that the recharge and discharge relationship at both these Nests, for this horizon, is broadly similar. Comparing Nest D with Nest B shows a similar linear relationship but with a different gradient (Fig. 6) because groundwater levels closer to the river at Nest B show a smaller change compared to Nest D. This trend is further amplified when comparison of Nest D is made with Nest A where the changes in groundwater level at Nest A

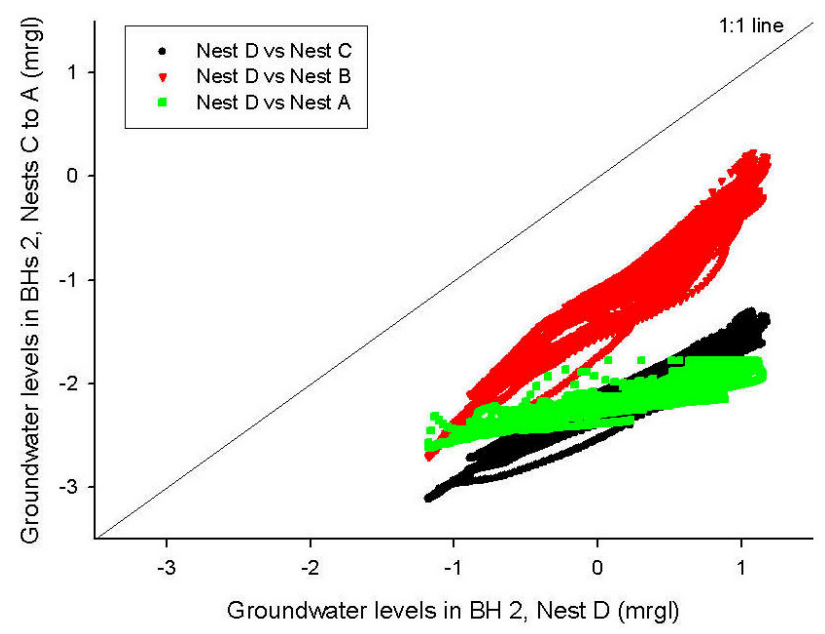

Fig. 7. Correlation between $\mathrm{BH} 2(\sim 10 \mathrm{~m})$ groundwater levels at Nest D and Nests C to A.

are almost negligible compared to those observed at Nest D. The increase in attenuation of the extremely fractured bedrock horizon groundwater response occurs with increasing proximity to the river and can be explained by groundwater discharge from this horizon into the river.

A similar plot for the less weathered shallow bedrock strata boreholes (BH 2, 10 $\mathrm{m}$ depth) is shown in Fig. 7 . Groundwater level changes observed at Nest B are similar to those observed at Nest D indicating a similar recharge/ discharge relationship. Groundwater level changes at $\mathrm{BH}$ 
2, Nest $\mathrm{C}$ are also broadly similar (only marginally smaller) compared to those at $\mathrm{BH} 2$, Nest D. However, a greater change in gradient is observed in the relationship between BH 2 at Nest D and BH 2 at Nest A (Fig. 7); it follows the pattern seen in the extremely fractured bedrock horizon (Fig. 6). Figure 7 shows much smaller groundwater level changes at Nest A, closest to the river, compared with Nest D. As for the extremely fractured bedrock horizon, this indicates a connection with the river and groundwater discharge to the stream. The fractures at a $\sim 10 \mathrm{~m}$ depth will be in close proximity to the bed of the river and, because groundwater heads are above the river level, the greatest discharge (from this horizon) into the river may be from the hyporheic zone, in addition to the bank discharge via truncated fractures indicated from Fig. $4 \mathrm{~b}$.

Figure 8 shows the relationship in groundwater levels between BH 1 and BH $2(\sim 1.5 \mathrm{~m}$ and $\sim 10 \mathrm{~m}$ depths respectively) for all the Nests. For nests $\mathrm{B}, \mathrm{C}$, and $\mathrm{D}$ there is a linear relationship between the water levels in BHs 1 and $\mathrm{BHs} 2$, but there is a threshold depth in the $1.5 \mathrm{~m}$ boreholes
(BHs1) where the relationship changes abruptly (marked $\mathbf{X}$ in Fig. 8). Because groundwater level changes close to the river were attenuated, the relationship between $\mathrm{BH} 1$ and BH 2 at Nest $\mathrm{A}$ is not as linear as for the other Nests however, when magnified, a similar change in gradient is also (again marked $\mathbf{X}$ ) seen at Nest A (Fig. 8). Because the $\sim 10 \mathrm{~m}$ groundwater horizon is probably confined, the change is most likely due to changes in the hydrogeological properties of the $\sim 1.5 \mathrm{~m}$ extremely fractured bedrock horizon. The water levels in $\mathrm{BHs} 1$ rise proportionately less than those in BHs 2, indicating a horizon where the hydraulic conductivity is greater. This change is at $0.4-0.5 \mathrm{~m}$ depth at Nests C, B and $\mathrm{A}$. The consistent depth at which this is observed for the three Nests closest to the river indicates a fast lateral flow pathway that extends down to the river. This lateral flow pathway at $0.4-0.5 \mathrm{~m}$ depth is situated at the interface below the soil profile and in the uppermost layers of the extremely fractured bedrock horizon that are the most weathered. This highlights a mechanism whereby rising groundwater is able to pick up chemical constituents from

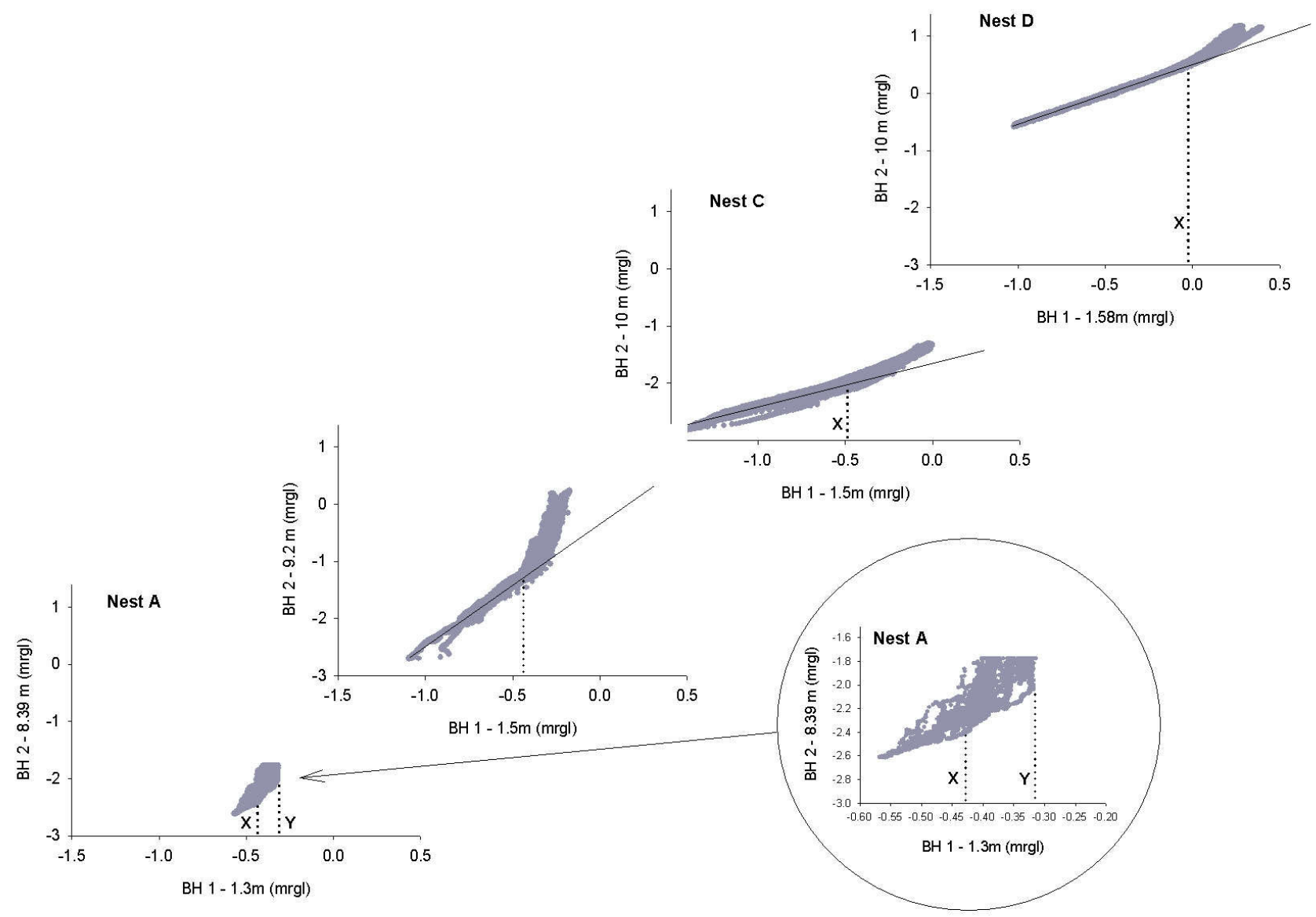

Fig. 8. Correlation between BH $1(\sim 1.5 \mathrm{~m})$ and BH $2(\sim 10 \mathrm{~m})$ groundwater levels observed at all Nests. 
the lower soil horizons before moving laterally quickly into the river.

A second change in gradient is evident at Nest $\mathrm{A}$ at a depth of about $0.32 \mathrm{~m}$ for BH 1 (marked $\mathbf{Y}$ in Fig. 8). This is the maximum groundwater level height recorded in $\mathrm{BH} 1$ and, because of the proximity to the river, represents a major connection with the river/riverbank such that further groundwater level increases in this horizon discharge directly into the stream.

At Nest D (Fig. 8), the change in gradient in the relationship is observed at the soil surface and not at $0.4-0.5 \mathrm{~m}$ depth and suggests that this lateral flow pathway is not present at Nest D. A further indication of reduced lateral flow at Nest D is the presence of upwelling groundwater in the form of a spring discharge observed during wet periods. Groundwater levels in BH 1, Nest D, become artesian probably because lateral and upward water flow is restricted; groundwater that can't move sideways has to force its way to the surface through the clay-rich soil horizon (most likely with a lower hydraulic conductivity) above. Soil piezometers also showed the presence of free water at Nest D.

However, no other upwelling groundwater in the form of a spring was seen elsewhere near the study site; no free water was observed in the upper soil horizons (data from piezometers) between Nest D and the river, even during storm events. This suggests that, for the most part, the lateral flow pathway is an effective mechanism for preferentially moving water downslope as the pressure head in the extremely fractured bedrock horizon increases during periods of rainfall.

\section{Conclusions}

This field study represents a site-specific physico-chemical analysis of the groundwater processes operating close to the stream channel of the Afon Hafren. The integration of detailed physical and chemical groundwater data has allowed the first stage development of a conceptual model that highlights the role of groundwater in stream flow generation. The fundamental findings are outlined below and will form the foundation on which to build a hydrological and hydrogeological model of upland catchment functioning.

- Bedrock groundwater is an important component in streamflow generation and likely represents a major control on stream water chemistry. In addition, different flow pathways and hydrological mixing in this deep reservoir (outlined below) can explain the attenuation in the chloride rainfall signal observed by many workers.

- Bedrock groundwater is not a homogeneous body that can be modelled using a single parameter. Observations in the riparian and lower hillslope zones highlight a complex aquifer most likely made up of confined depthspecific groundwater compartments. However, similar rapid responses to rainfall in all groundwater compartments suggest a similar rapid response to recharge to these compartments further upslope.

- The bedrock groundwaters at the study site were stratified chemically. This is a result of the different sub-surface flow pathways after recharge, resulting in different travel times for the waters sampled from depth specific horizons in this study.

- Groundwater discharge from the $\sim 1.5 \mathrm{~m}$ extremely fractured bedrock horizon to the river, in the form of bank discharge was identified.

- Groundwater discharge from the $\sim 10 \mathrm{~m}$ less weathered shallow bedrock horizon to the river, in the form of bank discharge and potentially from the river-bed, was identified.

- Over the study period, groundwater heads were always higher then those in the river; hence the tendency of flow will always be from the aquifer into the stream channel.

- Bedrock groundwater compartments (with different travel times and different groundwater chemistries) that discharge disproportionately into the stream have important implications for surface water quality.

- A horizon with a relatively greater lateral conductivity was identified at 0.4-0.5 m depth located, most probably, in the uppermost layer of the extremely fractured bedrock horizon. This layer was shown to be an important pathway for moving water downslope; discontinuities or restrictions in this horizon resulted in water being forced upwards into the soils. In the most extreme case, this resulted in groundwater discharge at the soil surface (a spring) during wet periods.

- Evidence of water upwelling into the soil has important implications for the source and, therefore, the chemistry of soil water. In other words, not all soil water is 'new' water but a mixture of 'new' rainwater and 'older' groundwater.

- Overall, it appears that near-river groundwater displacement by hydrodynamic pressure changes during rainfall events may move significant amounts of groundwater quickly into the soils and stream. The implications for this in terms of modelling stream water quality are enormous.

This is a site specific study and the heterogeneous nature 
of the catchment (including the presence of alluvial gravels in parts of the valley bottom and blanket peat in the headwaters) makes scaling up difficult. Further work is required at different scales and in different parts of the catchment the better to understand the relative contribution (both physical and chemical) of different catchment components to the streamflow hydrograph.

\section{Acknowledgements}

The authors would like to thank Andy Dixon for his expertise in drilling and completion of the boreholes to a very detailed specification. Thanks are also due to Alan Warwick and the Workshop staff who helped Andy in the novel design and installation of the wells. The Instrumentation section at $\mathrm{CEH}$ Wallingford provided a huge amount of field instrumentation and support. Thanks are also given to staff of the British Geological Survey who assisted with the drilling and water sampling. The authors also acknowledge Chris Soulsby, Chris Jackson, Martin Hodnett, John Roberts and Adrian Bath for useful discussions. Finally, the anonymous reviewers are thanked for detailed comments that have helped to improve this paper.

\section{References}

Chappell, N.A., Ternan, J.L., Williams, A.G. and Reynolds, B., 1990. Preliminary-analysis of water and solute movement beneath a coniferous hillslope in mid-Wales, U.K. J. Hydrol., 116, 201-215.

Chen, J., Wheater, H.S. and Lees, M.J., 2002. Identification of processes affecting stream chloride response in the Hafren catchment, mid-Wales. J. Hydrol., 264, 12-33.

Kirby, C., Newson, M.D. and Gilman, K., 1991. Plynlimon research: the first two decades. Institute of Hydrology Report No. 109.
Kirchner, J.W., 2003. A double paradox in catchment hydrology and geochemistry. Hydrol. Process., 17, 871-874.

Kirchner, J.W., Feng, X. and Neal, C., 2000. Fractal stream chemistry and its implications for contaminant transport in catchments. Nature, 403, 524-527.

Kirchner, J.W., Feng, X.H. and Neal, C., 2001 Catchment-scale advection and dispersion as a mechanism for fractal scaling in stream tracer concentrations. J. Hydrol., 254, 82-101.

Neal, C. and Rosier, P.T.W., 1990. Chemical studies of chloride and stable oxygen isotopes in two conifer afforested and moorland sites in the British uplands, J. Hydrol., 115, 269-283.

Neal, C., Christophersen, N., Neale, R., Smith, C.J., Whitehead, P.J. and Reynolds, B., 1988. Chloride in precipitation and streamwater for the upland catchment of river Severn, midWales; some consequences for hydrochemical models. Hydrol. Process., 2, 155-165.

Neal, C., Robson, A.J., Shand, P., Edmunds, W.M., Dixon, A.J., Buckley, D.K., Hill, S., Harrow, M., Neal M. and Reynolds, B., 1997. The occurrence of groundwater in the Lower Palaeozoic rocks of upland Central Wales. Hydrol. Earth Syst. Sci., 1, 318.

Robson, A.J., Neal, C., Hill, S. and Smith, C.J., 1993. Linking variations in short- and medium-term stream chemistry to rainfall inputs - some observations at Plynlimon, Mid-Wales. $J$. Hydrol., 144, 291-310.

Shand, P., Darbyshire, D.P.F., Gooddy, D.C., Edmunds, W.M. and Neal, C., 1997. ${ }^{87} \mathrm{Sr} /{ }^{86} \mathrm{Sr}$ as an indicator of flowpaths and weathering rates in the Plynlimon catchments, Wales, UK. BIOGEOMON: The $3^{\text {rd }}$ International Symposium on Ecosystem Behaviour, Journal of Conference Abstracts, 2 (2), 296. Cambridge Publications, UK.

Shand, P., Darbyshire, D.P.F., Gooddy, D.C., Darling, W.G., Neal, C., Haria, A.H. and Dixon, A.J., 2001. The application of $\mathrm{Sr}$ isotopes to catchment studies: The Plynlimon upland catchment of Central Wales. In: Water-Rock Interaction 10, R. Cidu (Ed.), Tenth Int. Symp. Water-Rock Interaction, Sardinia, Italy. Balkema, Rotterdam, The Netherlands. 1577-1580.

Sklash, M.G., Beven, K.J., Gilman, K. and Darling, W.G., 1996. Isotope studies of pipeflow at Plynlimon, Wales, UK. Hydrol. Process., 10, 921-944.

Soulsby, C., 1995. Influence of sea-salt on stream water chemistry in an upland afforested catchment. Hydrol. Process., 9, 183196. 